\title{
FIVE FORMS OF PALINURID PHYLLOSOMA LARVAE FROM JAPAN
}

AUTHOR(S):

Murano, Masaaki

CITATION:

Murano, Masaaki. FIVE FORMS OF PALINURID PHYLLOSOMA LARVAE FROM JAPAN. PUBLICATIONS OF THE SETO MARINE BIOLOGICAL LABORATORY 1971, 19(1): 17-25

ISSUE DATE:

1971-06-30

URL:

http://hdl.handle.net/2433/175658

RIGHT: 


\title{
FIVE FORMS OF PALINURID PHYLLOSOMA LARVAE FROM JAPAN
}

\author{
MASAAKI MURANO
}

Ocean Research Institute, University of Tokyo

With 10 Text-figures

Japanese spiny lobster has been highly appraised in the coastal fishing industry along the Pacific coasts of Central and Southwestern Japan. There are not a few studies on this species, but our knowledge of the ecological aspects of its phyllosoma stages such as life history, distribution and so on has been severely restricted. Two reasons are thought for this. In the first place, the phyllosoma larvae of Japanese spiny lobster are hardly collected from Japanese waters, especially from coastal waters of Central Japan. Secondly, it is difficult to know which is the larval from of Japanese spiny lobster since there are five forms of phyllosoma larvae of Panulirus in the seas of Southwestern Japan where the larvae are abundantly collected.

In the present paper, the descriptions of five forms of the palinurid phyllosoma larvae collected from the neighbouring waters of Japan are given as a step for the ecological study on the larval stage of Japanese spiny lobster in the future.

\section{Materials}

The materials were collected by horizontal or oblique tows of plankton and larva nets of various types by research vessels, Hakuho-maru and Tansei-maru of the Ocean Research Institute, University of Tokyo, Umitaka-maru and Shinyo-maru of the Tokyo University of Fisheries, and Nagasaki-maru of the Nagasaki University. As the classification of the phyllosoma larvae is aimed at in this paper, the phyllosoma larvae of the ultimate or penultimate stage which well indicate the specific characteristics are used in the present work.

\section{Description of phyllosoma larvae}

\section{Form $A$}

Two specimens, 30.1 and $31.0 \mathrm{~mm}$ long and belonging to the final stage, are collected. Cephalic shield is elongate and elliptical, and much narrower than thorax;

Publ. Seto Mar. Biol. Lab., XIX (1), 17-25, 1971. (Article 2) 
Table 1. The sampling position and the measurements of the phyllosoma larvae considered in the present work

\begin{tabular}{|c|c|c|c|c|c|c|c|c|c|}
\hline & $\begin{array}{l}\text { Specimen } \\
\quad \text { No. }\end{array}$ & Stage & $\begin{array}{l}\text { Position of } \\
\text { collection }\end{array}$ & $\begin{array}{c}\text { Body } \\
\text { length }\end{array}$ & $\begin{array}{l}\text { Cephalon } \\
\text { width }\end{array}$ & $\begin{array}{l}\text { Cepahlon } \\
\text { length }\end{array}$ & $\begin{array}{l}\text { Thorax } \\
\text { width }\end{array}$ & $\begin{array}{l}\text { Width/ } \\
\text { length in } \\
\text { Cephalon }\end{array}$ & $\begin{array}{l}\text { Cephalon/ } \\
\text { Thorax in } \\
\text { width }\end{array}$ \\
\hline \multirow[t]{2}{*}{ Form A } & 643 & $\mathrm{XI}$ & $\begin{array}{r}28-01.9 \mathrm{~N} \\
135-48.4 \mathrm{E}\end{array}$ & 30.1 & 11.1 & 18.3 & 13.0 & 0.61 & 0.85 \\
\hline & 644 & XI & $\begin{array}{r}27-57.8 \mathrm{~N} \\
130-23.6 \mathrm{E}\end{array}$ & 31.0 & 11.2 & 18.7 & 14.2 & 0.60 & 0.79 \\
\hline Form B & 646 & $\mathrm{x}$ & $\begin{array}{r}28-06.1 \mathrm{~N} \\
134-04.5 \mathrm{E}\end{array}$ & 32.1 & 14.6 & 21.4 & 15.4 & 0.68 & 0.95 \\
\hline \multirow[t]{2}{*}{ Form $\mathrm{C}$} & 634 & XI & $\begin{array}{r}00-08.7 \mathrm{~S} \\
161-53.7 \mathrm{E}\end{array}$ & 42.3 & 19.7 & 26.4 & 19.6 & 0.74 & 1.0 \\
\hline & 635 & $\mathrm{XI}$ & $\begin{array}{r}24-00.0 \mathrm{~N} \\
142-00.3 \mathrm{E}\end{array}$ & 40.1 & 18.4 & 24.1 & 18.7 & 0.76 & 0.98 \\
\hline \multirow[t]{4}{*}{ Form D } & 636 & XI & $\begin{array}{r}34-44.5 \mathrm{~N} \\
14 \mathrm{I}-34.1 \mathrm{E}\end{array}$ & 28.5 & 13.5 & 18.1 & 11.8 & 0.75 & 1.15 \\
\hline & 637 & XI & $\begin{array}{r}24-59.8 \mathrm{~N} \\
141-57.8 \mathrm{E}\end{array}$ & 26.6 & 12.9 & 16.5 & 11.7 & 0.78 & 1.11 \\
\hline & 6 & XI & $\begin{array}{r}26-00.9 \mathrm{~N} \\
142-00.4 \mathrm{E}\end{array}$ & 29.0 & 13.2 & 18.0 & 12.4 & 0.73 & 1.06 \\
\hline & 4 & XI & $\begin{array}{l}\text { South } \\
\text { China Sea }\end{array}$ & 25.4 & 11.8 & 16.3 & 10.7 & 0.72 & 1.10 \\
\hline \multirow[t]{2}{*}{ Form E } & 640 & $\mathrm{X} ?$ & $\begin{array}{r}36-06.8 \mathrm{~N} \\
142-21.3 \mathrm{E}\end{array}$ & 21.3 & 9.8 & 15.0 & 9.1 & 0.65 & 1.07 \\
\hline & 641 & $\mathrm{X} ?$ & $\begin{array}{r}37-50.0 \mathrm{~N} \\
142-40.2 \mathrm{E}\end{array}$ & 22.8 & 10.3 & 15.7 & 9.3 & 0.66 & 1.11 \\
\hline
\end{tabular}

the maximum width is located somewhat nearer to posterior part than to the middle of cephalon; posterior margin is narrowly rounded. Posterior lateral margins of cephalic shield intersect those of thorax at just the rear of third maxilliped. Second maxilliped is slender, five-segmented; the segments are of the following proportional

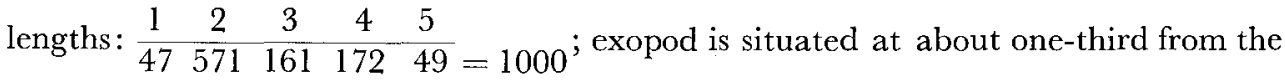
base of second segment, and is less than one-third of this segment in length; setae on the exopod are few, only one to three pairs are provided with. Third maxilliped and first to fifth pereiopods are unarmed with spines on the coxal segment.

Two specimens of this form have been given by Osmima (1942) from the neighbouring seas of Japan. The present form is distributed in the offing of the Pacific coasts from Kyushu Island to Honshu Island (Fig. 3).

\section{Form B}

The maximum specimen in the collection of this form was $32.1 \mathrm{~mm}$ in the body length. Among the phyllosoma larvae of genus Panulirus, this species is considerably large, since the specimen is estimated to be at the tenth stage. Cephalic shield is elliptical and its maximum width is located slightly closer to the anterior end than to the middle of the length; anterior lateral margins are evenly rounded and not forming 


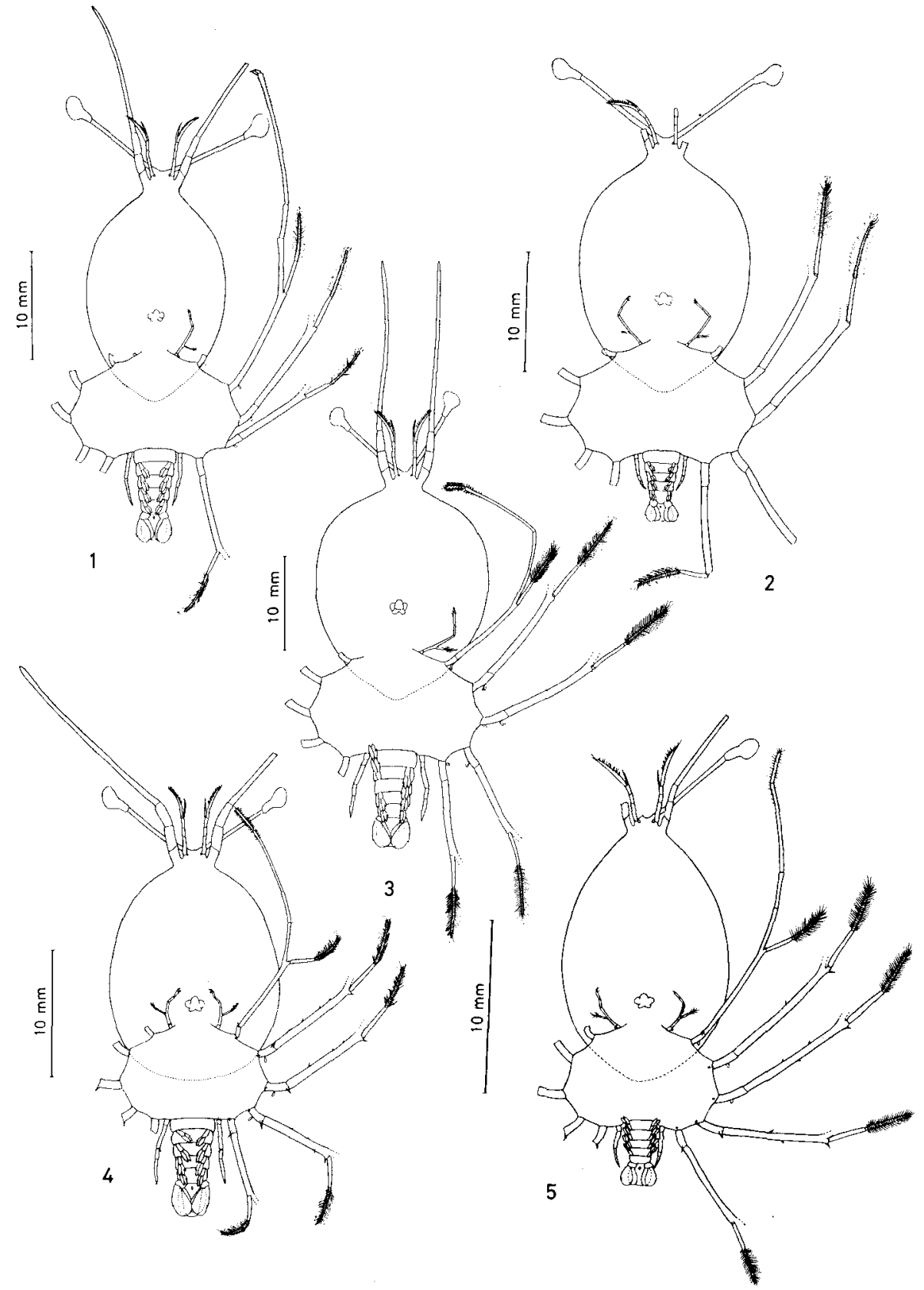

Figs. 1-5. Palinurid phyllosoma larvae.

1, Form A, stage XI; 2, Form B, stage X; 3, Form C, stage XI; 4, Form D, stage XI ; 5, Form E, stage $X$ ?. 
a pronounced shoulder; posterior margin is narrowly rounded. Margins of cephalic shield and thorax are crossing at just the rear of third maxilliped. The thorax is slightly broader than the cephalon (100:95). Second maxiliped is slender and five-

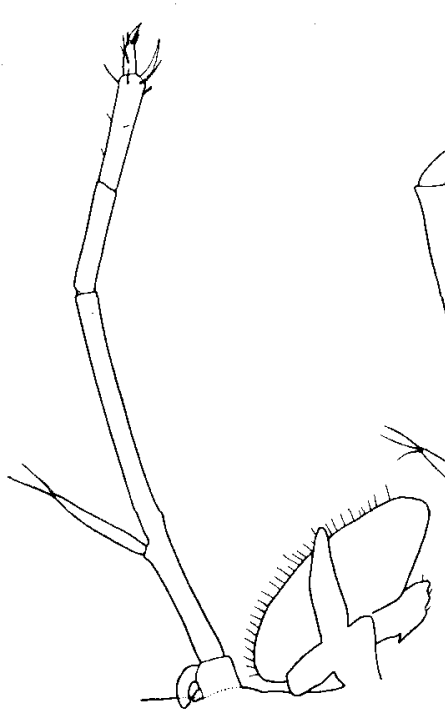

6

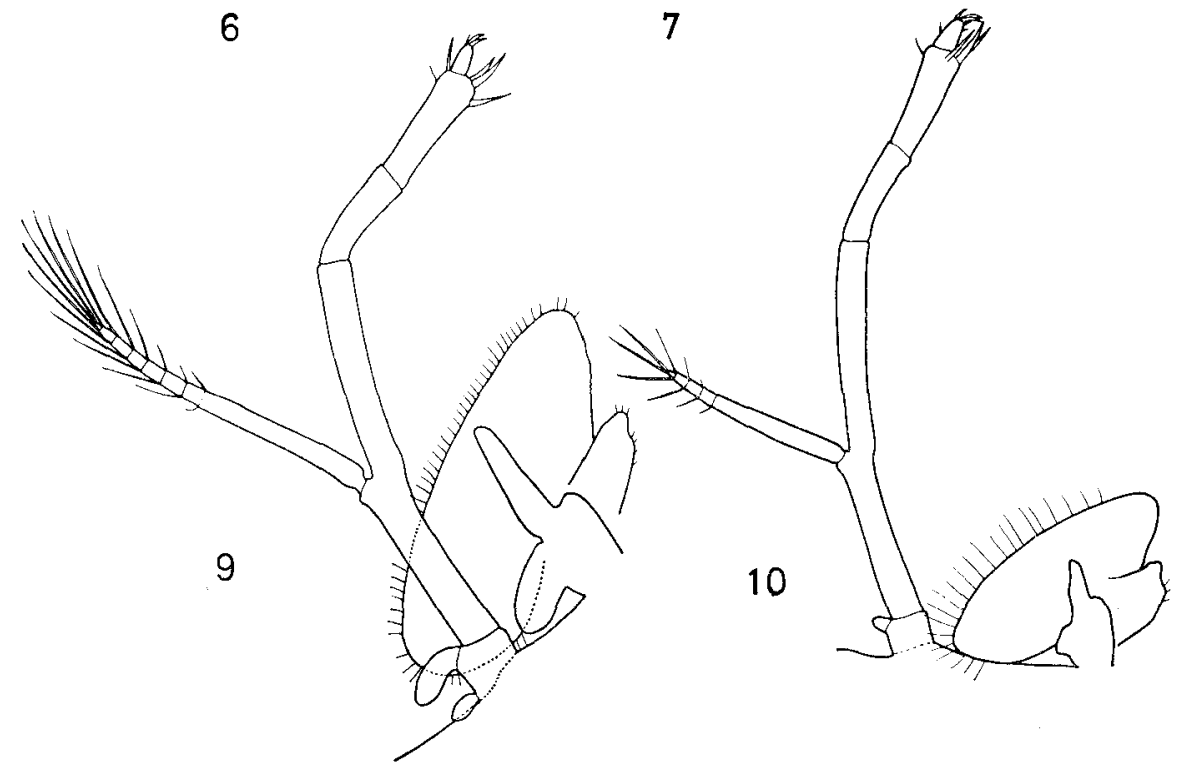

Figs. 6-10. Second maxilla, first and second maxillipeds.

6, Form A; 7, Form B; 8, Form C; 9, Form D; 10, Form E. 
segmented, and of the following proportional lengths: \begin{tabular}{cccccc}
1 & 2 & 3 & 4 & 5 \\
\hline 34 & 445 & 115 & 364 & 42
\end{tabular}$=1000$; exopod is situated at about one-third from the base of second segment and is about onefifth of the segment in length; the apex is armed with one or two pairs of setae in this stage.

The present form is very closely allied to the phyllosoma larvae of $P$. marginatus from Hawaiian waters reported by Johnson (1968). This is the first record of occurrence from the Japanese waters.

\section{Form $C$}

Two specimens of the last stage were collected. They are 40.1 and $42.3 \mathrm{~mm}$

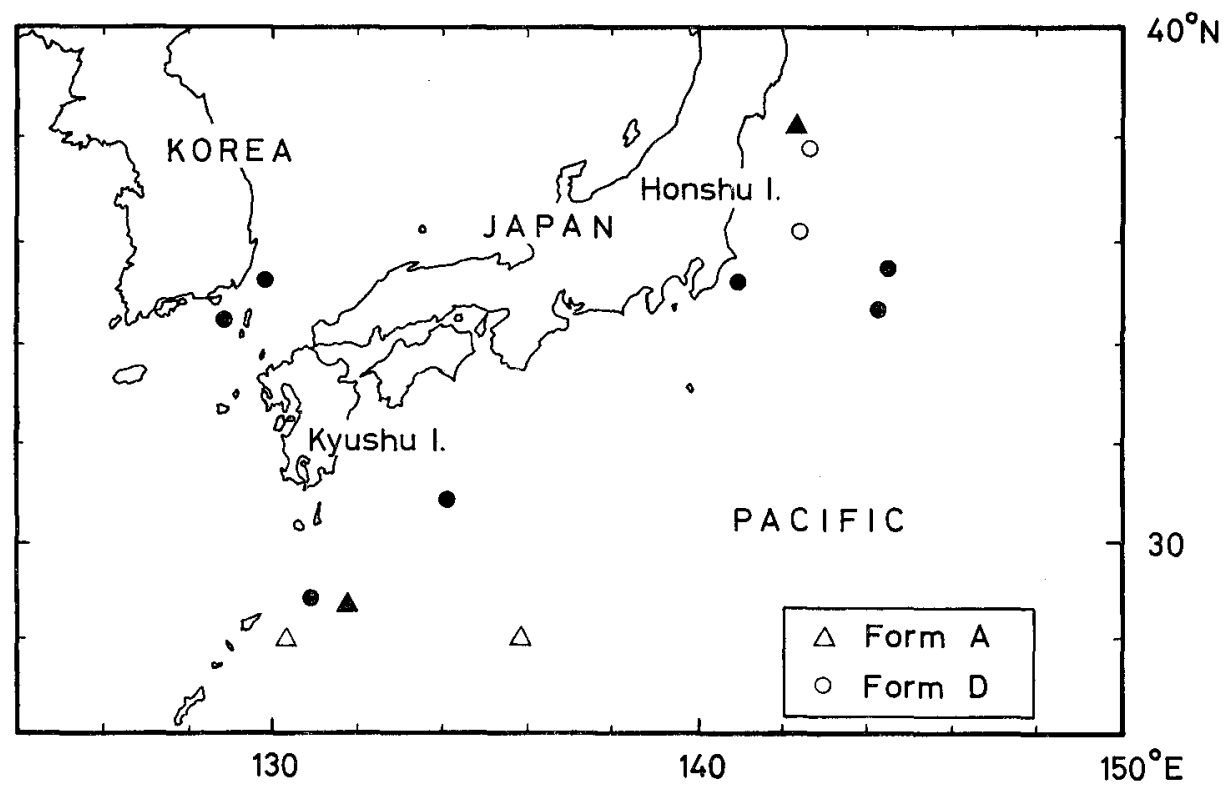

Fig. 11. The distribution of Form A and Form D in the neighbouring seas of Japan. Open triangles and circles indicate the present specimens, and solid triangles and circles indicate OsHIMA's ones.

in body length, and are fairly large in comparison with other palinurid phyllosoma larvae. Cephalic shield is nearly equal to thorax in width; the maximum width is located a little closer to the anterior end than to the middle of the length of cephalon. Anterior lateral margins are convex and are forming rather distinct shoulders. Posterior margin is narrowly rounded. Margins of cephalon and thorax cross each other at just the rear of third maxilliped. Second maxilliped is slender and five-segmented; the semgents are of the following proportional lengths: \begin{tabular}{lcccc}
1 & 2 & 3 & 4 & 5 \\
\hline 46 & 591 & 137 & 183 & 43
\end{tabular}$=1000$; exopod is seven-jointed and situated at about one- 
third from the base of second segment; the length of exopod is about one-third of this segment.; Third maxilliped and first to fifth legs are unarmed with spines in the coxal segment.

This form has been recorded from the Indian Ocean by SAIsHo (1966) as Panulirus $\alpha$ and from Hawaiian waters by Johnson (1968) under the name of $P$. penicillatus. The present collection is the first record from the Japanese waters.

\section{Form $D$}

In the present collection four specimens belonging to the final stage and of the lengths 25.4 to $29.0 \mathrm{~mm}$ were obtained. Cephalic shield is clearly wider than thorax; the maximum width is situated somewhat closer to the posterior end than to the middle of the length of cephalon; posterior margin is extremely broadly rounded. Cephalic shield is just extending to the coxa of first pereiopod. Second maxilliped is robust, five-segmented; the segments are of the following proportional lengths: $\begin{array}{ccccc}1 & 2 & 3 & 4 & 5 \\ 56 & 574 & 148 & 178 & 44\end{array}=1000$; the exopod is located at the middle of second segment and is about four-fifths of this segment in length. Third maxilliped and first pereiopod are armed with a single spine on the ventral surface near the distal margin of the coxa. Each of second to fourth pereiopods is armed with a single prominent spine on the dorsal surface near the distal margin of the coxa. A conspicuous spine is present on the second segment at the base of the exopod of first to third pereiopods. Fifth pereiopod is armed with a single spine on the dorsal surface near the distal margin of second segment.

This form has been recorded from the Indian Ocean under the name of $P$. penicillatus by Prasad and TAmpi (1955) and Saisho (1966). The present record, therefore, is a new in the Japanese waters.

\section{Form $E$}

Two specimens of 21.3 and $22.8 \mathrm{~mm}$ belong to the latest stage in the present collection, but it appears that these are identified to be at the tenth stage but not at the last stage, judging from the degree of development in abdomen and second maxilliped. Cephalic shield is oval in outline and is slightly wider than thorax; the maximum width is situated somewhat nearer to the thorax than to the middle of the length of cephalon; anterior half is more narrowly rounded than in the posterior half. Cephalic shield is extending beyond the coxa of third maxilliped. Second maxilliped is rather robust and five-jointed; the segments are of the following proportional lengths: $\frac{1 \quad 2 \quad 3 \quad 4 \quad 5}{48578 \quad 157 \quad 164 \quad 53}=1000$; exopod is located a little nearer to the base than to the middle of second segment, and at about half the length of its segment, armed with four or five pairs of setae. Third maxilliped is armed with a signle spine on ventral surface of the coxa. Third and fourth pereiopods are armed with a single 
spine on dorsal surface of the coxa. A prominent spine is provided with on the second segment at just the base of the exopod of first to third pereiopods.

Form $\mathrm{E}$ has been described from adjacent waters of Japan by Oshima (1942), and it is distributed in the Korea Strait and in the offing of the Pacific coasts of Japan from Kyushu Island to Honshu Island (Fig, 3).

\section{Discussion}

Species identification of palinurid phyllosoma larvae is difficult because of the difficulty of rearing from egg to puerulus or later phyllosoma stages. The phyllosoma larvae of which the species is identified have been decided from the agreement of the distribution of adults with the occurrence of phyllosoma larvae. From Japan, eight species of the genus Panulirus have been recorded as follows: P. japonicus (Von Srebold), $P$. penicillatus (Olrvier), $P$. versicolor (Latreille), P. ornatus (MilneEdwards), $P$, longipes (Milne-Edwards), $P$. homarus (Linnaeus), $P$. polyphagus (Herbst) and $P$. dasypus (FArricius). Except two species, $P$. dasypus and $P$. polyphagus, which have only one or two times of recording from Japan, other species enter in a large or small number into the commercial catch in Southwestern Japan. Therefore, it is hard that the species name is decided by the agreement in the distribution of adults and phyllosoma larvae.

$P$. japonicus is an economically important species along the Pacific coasts of Central and Southwestern Japan. This species is caught in Southwestern Japan west of Kagoshima, mixed with a considerable number of $P$. versicolor and $P$. ornatus. But in Central Japan in the sea area from Kii Peninsula to Boso Peninsula, this species alone is caught and other palinurid species are hardly found in this area. Therefore, if we conduct the survey of palinurid phyllosoma larvae in this area, for instance in Sagami and Suruga Bays where there are good fishing grounds for $P$. japonicus along the coasts, the survey is expected to augment the knowledge of the phyllosoma larvae of this species, but at present the collection of these larvae is very difficult, especially those of the middle and later stages have not been found at all from the plankton samples collected by the ORI plankton net with the mouth diameter of $160 \mathrm{~cm}$, in spite of the efforts of a large number of collecting. This fact has resulted in the present status that their life cycle is unknown even now, and at the same time this fact involves a very interesting problem, how to replenish the resources of $P$. japonicus.

Form $\mathrm{E}$ in the present work is surely identified with Form $\mathrm{E}$ discribed by OsHima (1942). He suggested that his Form $\mathrm{E}$ was $P$. japonicus because it well agreed with newly hatched phyllosoma of $P$. japonicus described by NakAzAwa in two respects, thorax being somewhat smaller than the cephalon in width, and the first to third pereiopods being armed with a single prominent coxal spine.

The present author observed in detail two specimens of phyllosoma larvae of $P$. japonicus, 6.6 and $5.8 \mathrm{~mm}$ in the body length, which were hatched and reared in 
the laboratory through the kindness of Mr. NonAKa. In these specimens the cephalon is far narrower than the thorax and there is a noticeable difference between newly hatched phyllosoma larvae as already described and figured by SAIsHo (1962). With respect to the coxal spine of the third maxilliped and pereiopods, in the larger specimen it was only found on the first and third pereiopods of the left side and on the first pereiopods of the other side, in the smaller one on pairs of the third maxilliped and on the first and third pereiopods. In these specimens the coxal spines may be broken off, since SAIsHo figured the coxal spine on the third maxilliped and on the first to fourth pereiopods. It is, however, certain that the coxal spines become relatively smaller in proportion to the progress of the stages. Therefore in P. japonicus it is questionable whether they still remain or not on the coxa until the final phyllosoma stage. Judging from the fact that the width of the cephalon is much narrower than that of the thorax at middle stages of 5 to $7 \mathrm{~mm}$ in the body length, it may be more reasonable that Form A in the present paper is identified with P.japonicus. However, the author wished to avoid a conclusion for the species names of Form $\mathrm{A}$ and Form $\mathrm{E}$ under the existing state that the conclusive morphological characteristics which are to be identified with $P$. japonicus have not been given.

Until now, under the species name of $P$. penicillatus two forms of phyllosoma larvae were reported from the Indian Ocean by PRASAD and TAMPI (1959) and from Hawaiian waters by Johnson (1968). Form D in the present work is identical with the former, and Form $\mathrm{C}$ is referred to the latter. There are many difference between two forms in the morphological feature of the shape of cephalic shield, the length of the exopod of the second maxilliped and the presence or absence of a spine on the distal posterior dorsal angle in the coxal segment and of a prominent spine on the second segment of the pereiopods at the base of the exopod. JoHnson concluded to identify Form $\mathrm{G}$ with $P$. penicillatus through the correspondence of the distribution of their adults with the occurrence of phyllosoma larvae in adjacent waters of Hawaiian Archipelago. As mentioned above, however, it is difficult in the neighbouring waters of Japan to make species identification from such a correspondence of distribution. The author is compelled to be pending to say which is really phyllosoma larvae of $P$. penicillatus.

Form B is very closely allied to the phyllosoma larvae of P. marginatus (Quoy and GAIMARD) which are described and illustrated by JoHnson from Hawaiian Archipelago. However, this species is distributed in only Hawaiian Islands and has not been recorded from Japan and its neighbouring area. It is difficult to consider that the specimen in the present work came from Hawaiian Islands, because the distance is for the planktonic life too large to go drifting and there are no currents by which they are carried away. It seems that Form B may be referred to $P$. japonicus or $P$. longipes which is the species most closely related with $P$. marginatus. 


\section{Acknowledgements}

Professor Ryuzo Marumo of the Ocean Research Institute, University of Tokyo, has kindly encouraged the present author throughout the work. The author wishes to express his thanks to Mr. Makoto NonAka of the Shizuoka Prefectural Fishery Experimental Station, for giving the opportunity of examining the phyllosoma larvae reared in his laboratory. Thanks are also due to Associate Professor Yoshie Dotsu of the Faculty of Fisheries, Nagasaki University, and to Ex-Professor Katsuzo KURonuma of the Tokyo University of Fisheries and Dr. Hitoshi IDA of the University Meseum, University of Tokyo, for gifts of the phyllosoma larvae collected by the research vessels, Nagasaki-Maru, Umitaka-maru and Tansei-maru.

\section{REFERENCES}

Oshima, Y. (1942): On the phyllosoma of the genus Panulirus. Suisan Gakukaiho, 9, 36-44.

George R. W. and L. B. Holthuis (1965): A revision of the Indo-West Pacific spiny lobsters of the Panulirus japonicus group. Zool. Verhand., 72 1-36, 5 pls.

HARAda, E. (1965): Zoogeographical aspects of Palinura collected in the Kii District. Nankiseibutsu, 7, 35-42.

Johnson, M. W. (1968): Palinurid phyllosoma larvae from the Hawaiian Archipelago (Palinuridea). Crustaceana, suppl. 2, 59-79.

Kubo, I. (1954): Systematic studies on the Japanese macrurous decapod Crustacea. 3. On the palinurid lobsters. Journ. Tokyo Univ. Fish., 41, 95--105.

Prasad, R. R. and P. R. S. TAmpi (1959): On a collection of palinurid phyllosomas from the Laccadive Seas. Journ. Mar. Biol. Ass. India, 1, 143-164.

SAIsro, T. (1962): Notes on the early development of phyllosoma of Panulirus japonicus. Mem. Fac. Fish. Kagoshima Univ., 11, 18-23.

SAISho, T. (1966): Studies on the phyllosoma larvae with reference to the oceanographical conditions. Mem. Fac. Fish. Kagoshima Univ., 15, 177-239. 